\title{
FOSTERING STUDENTS' CRITICAL THINKING BY PROJECT-BASED LEARNING
}

\author{
Pryla Rochmahwati \\ STAIN Ponorogo \\ rpryla@yahoo.com
}

\begin{abstract}
This research focused on fostering students' critical thinking through ProjectBased Learning. The design of the research was descriptive qualitative method. The subjects were the lecturer of TEFL 1 course and 25 students in C class of the fourth semester of STAIN Ponorogo who took TEFL 1 course. The instruments used are in the form of observation sheet and interview guideline. The data analysis applied in this research used data reduction, data display, and conclusion drawing. The findings showed that the implementation Project-Based Learning that fosters the students' critical thinking in TEFL class are through the following steps: (1) Discussing the materials about English Language Teaching Method, (2) working with the group to construct scenario of teaching practice, (3) practicing the scenario, (4) recording the teaching practice into video, and (5) evaluating the video product. Moreover, the result of interview indicates that the students showed significantly positive attitude toward the implementation of Project-Based Learning. Finally, English teachers are recommended to implement Project-Based Learning in EFL class since it facilitates the students to build their critical thinking.
\end{abstract}

\section{Keywords: critical thinking, Project-Based Learning}

Nowadays, it is essential for everyone especially university students to have good thinking skills and abilities in order to meet the demands of modern life. It indicates that there is no longer possible to teach all students all they need to know, only when learners are able to avail themselves of each learning opportunity, rather than simply react to various stimuli from the lecturer in their language learning process. The situation calls for the urgent need of fostering students' critical thinking.

Critical thinking is one of the thinking skills that should be considered in designing and improving language curriculum because the world we live in is getting more complex to understand, and how we process information has become more important than specific details.
Halverson (2014) defines critical thinking as: "to think critically about an issue is to consider that issue from various perspectives, to look at and challenge any possible assumptions that may underlie the issue and to explore its possible alternative." This ability can be improved by teaching students ways to develop their thinking abilities. Consequently, they will have the benefits which are obtained due to their engagement in thinking and sharing thoughts with other learners.

Additionally, Fahim \& Sa'eepour (2011:867) state that critical thinking has been defined in many different ways. Philosophers have tended to focus on the nature and products of critical thinking, while psychologists have concentrated on the process of cognition, and seeking the conclusion in empirical research. On the 
other hand, some educators have drawn on both psychology and philosophy to develop a rigorous theory of critical thinking for teaching

Moreover, Beyer (1985) states that critical thinking is the ability to collect, evaluate and make use of information effectively and appropriately. Critical thinking is the ability to think for one's self and reliably and responsibly make those decisions that affect one's life. Critical thinking is also critical inquiry. Therefore, critical thinkers investigate problems, ask questions, pose new answers that challenge the status quo, discover new information that can be used for good or ill, question authorities and traditional beliefs, challenge received dogmas and doctrines, and often end up possessing power in society greater than their numbers.

Glaser in Fisher (2001:3) identified the abilities which underlie critical thinking are to recognize problem, find workable means for meeting those problems, gather pertinent information, recognize unstated assumption, comprehend and use language with accuracy, clarity and discrimination, interpret data, appraise evidence and evaluate statement, recognize the existence of logical relationship, draw conclusion and generalization, put to test the generalization and conclusion at which one arrives, reconstruct one's pattern of believe, and render accurate judgment about specific things and qualities in everyday life.

Referring to the implementation of project-based learning in language teaching, Bas (2011) asserts that projectbased learning is an instructional method centered on the learner. Students develop a question and are guided through research under the lecturer's supervision. Instead of using a rigid lesson plan that directs a learner down a specific path of learning outcomes or objectives, projectbased learning allows in-depth investigation of a topic worth learning more about (Helm, 2001).

Project-based learning is based on the constructivist learning theory, which finds that learning is deeper and more meaningful when students are involved in constructing their own knowledge. Constructivism is a theory based on observation and scientific study about how people learn. People construct their own understanding and knowledge of the world, through experiencing things and reflecting on those experiences (Piaget, 1969; Vygotsky, 1978; Perkins, 1991).

At Ponorogo Islamic State College, the fourth semester of undergraduate students is required to take Teaching English as Foreign Language (TEFL) course. This objective of the TEFL course is to provide the students with knowledge, skills and the basic principles of teaching and learning process dealing with various approaches, methods, and techniques in TEFL and language learning strategies. Furthermore, the students are expected critically learn and keep abreast with current issues concerning teachinglearning methods obtained from various sources such as textbooks, journal articles or seminar papers (TEFL Syllabus of English Department, 2013).

In order to achieve the objective of TEFL course, lecturers are facing challenges in designing innovative pedagogical approaches with the objective to set young minds thinking and to promote critical thinking. Project-based 
learning is considered effective to foster critical thinking. Project-based learning is an authentic learning model or strategy in which students plan, implement, and evaluate projects that have real-world applications beyond the classroom (Westwood, 2008). It supports students' engagement in problem-solving situations (Doppelt, 2003) and enhances the quality of learning and leads to higher-level cognitive development. It implies that students become more engaged in learning when they have a chance to dig into complex, challenging, and sometimes even chaotic problems that is closely similar to real life.

The result of preliminary observation on the $3^{\text {rd }}$ of June, 2014 showed that the lecturer explained about what kind of project that would be done during the course. The students seemed enthusiast in responding the lecturer's explanation. Referring to the theoretical and empirical data above, therefore, this research reports the implementation of Project-Based Learning in TEFL 1 class, its problem, and the students' responses on its implementation.

\section{METHOD}

The design of the research was descriptive qualitative method, as Bogdan $\mathcal{E}$ Biklen (1998:25) define the qualitative approach as a research procedure which produces a descriptive data such as verbal or nonverbal utterances or words from the object being observed. The research subjects were the lecturer of TEFL 1 course and 25 students in C class of the fourth semester students of STAIN Ponorogo who took TEFL 1 course. The instruments used are in the form of observation sheet, and interview guideline. Miles \& Huberman's (1994:24) view of qualitative data analysis consisting of data reduction, data display, and drawing conclusion was employed in the research.

\section{FINDINGS AND DISCUSSIONS}

\section{The Implementation of Project-Based} Learning in TEFL 1 Course

Referring to the result of observation and interview, it can be implied that the steps in implementing of Project-Based Learning that build students' critical thinking in TEFL class are as follows.

\section{Discussing the Materials to Get Better Understanding}

In discussing the materials of English language teaching method, the lecturer divided the class into 7 groups. Each group discussed the selected ELT Method, namely, (1) Grammar Translation Method, (2) Direct method, (3) Audio Lingual Method, (4) Suggestopedia, (5) Silent Way, (6) Community Language Learning, and (7) Total Physical Responses. Each group had to make summary on the selected method in terms of definition, characteristics, the strengths and weaknesses and the underlie techniques, and then it had to be presented in front of the class.

The students applied various techniques and media to present the materials. They used video, picture, LCD as media and demonstrated how to teach by the selected method. The activities are shown in the following figures. 

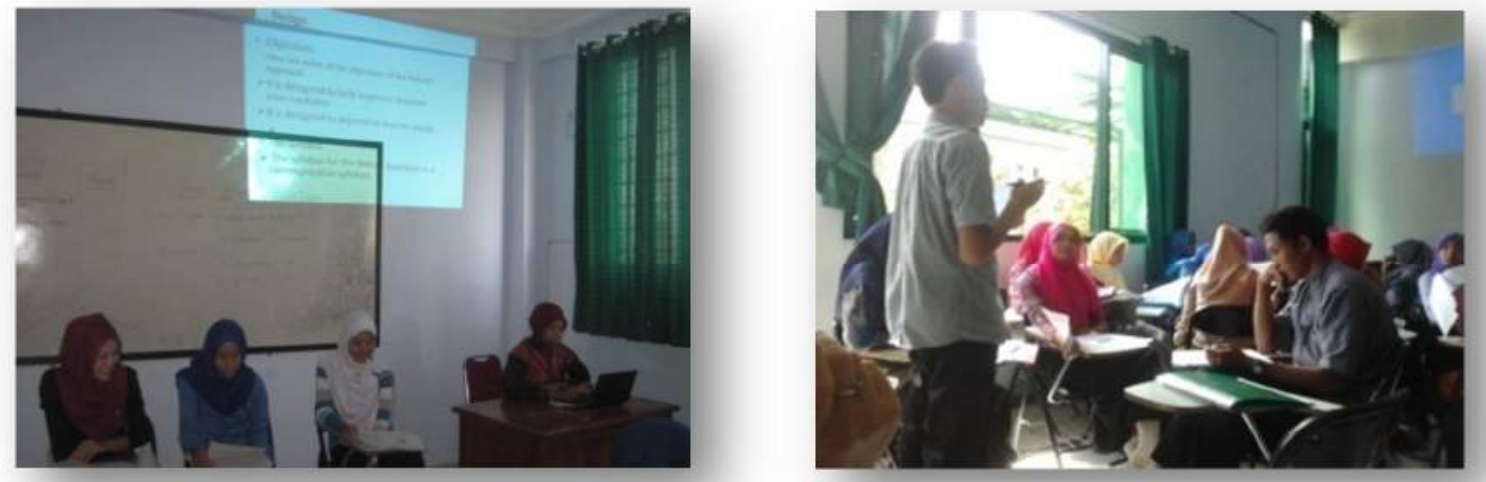

Figure 1. Classroom Presentation
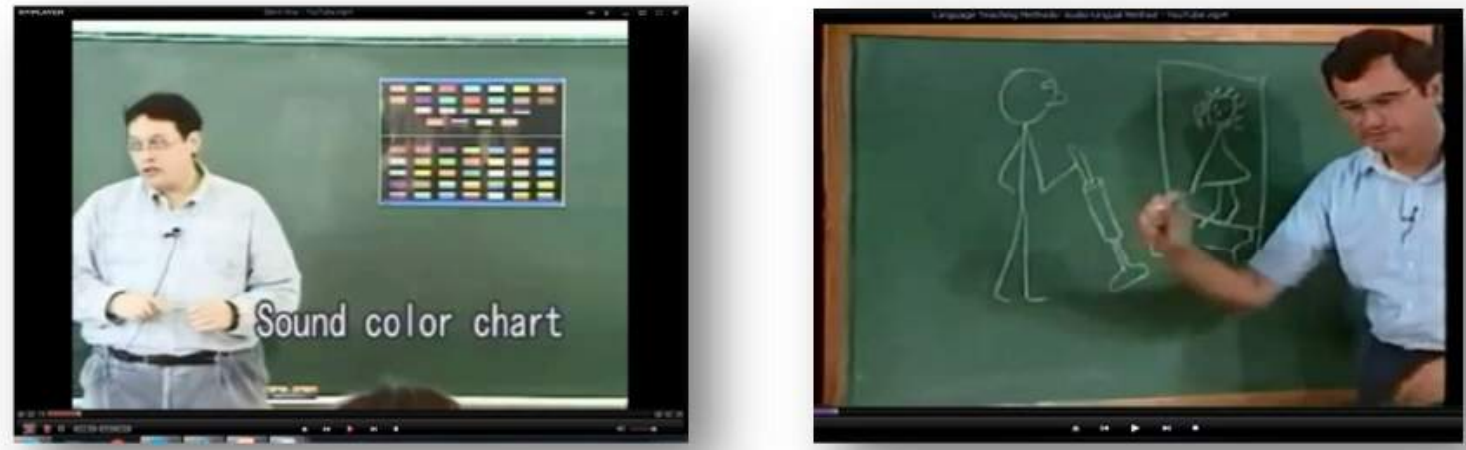

Figure 2. ELT Method Video from YouTube as Media

Working with the Group to Construct Scenario of Teaching Practice

After the students had discussed and got the point on the ELT Method, the

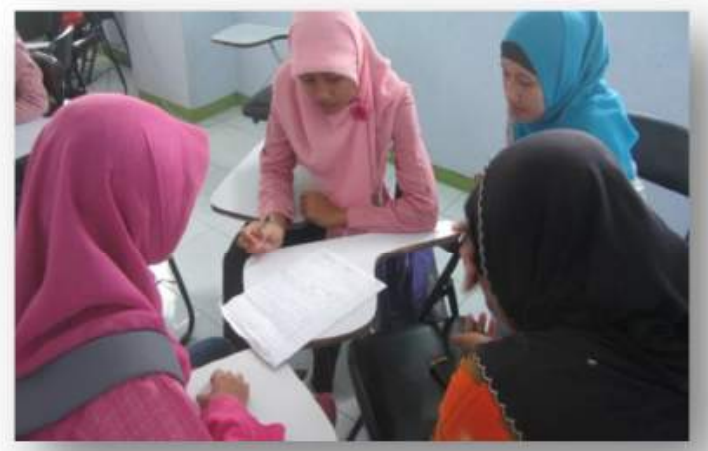

lecturer guided them to construct a scenario of teaching practice of the selected method. The activity is shown in the following figure.

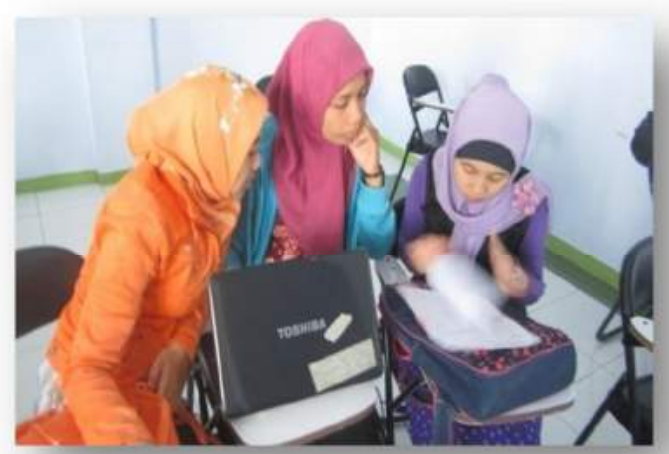

Figure 3. Constructing Teaching Practice Scenario

\section{Practicing the Scenario/Micro Teaching}

Finished constructing scenario, the lecturer asked the students to practice their scenarios with the peers. This activity was needed as a feedback to improve the scenario, whether the dialogue needed to use, omit or revise. The following figure showed the activity. 

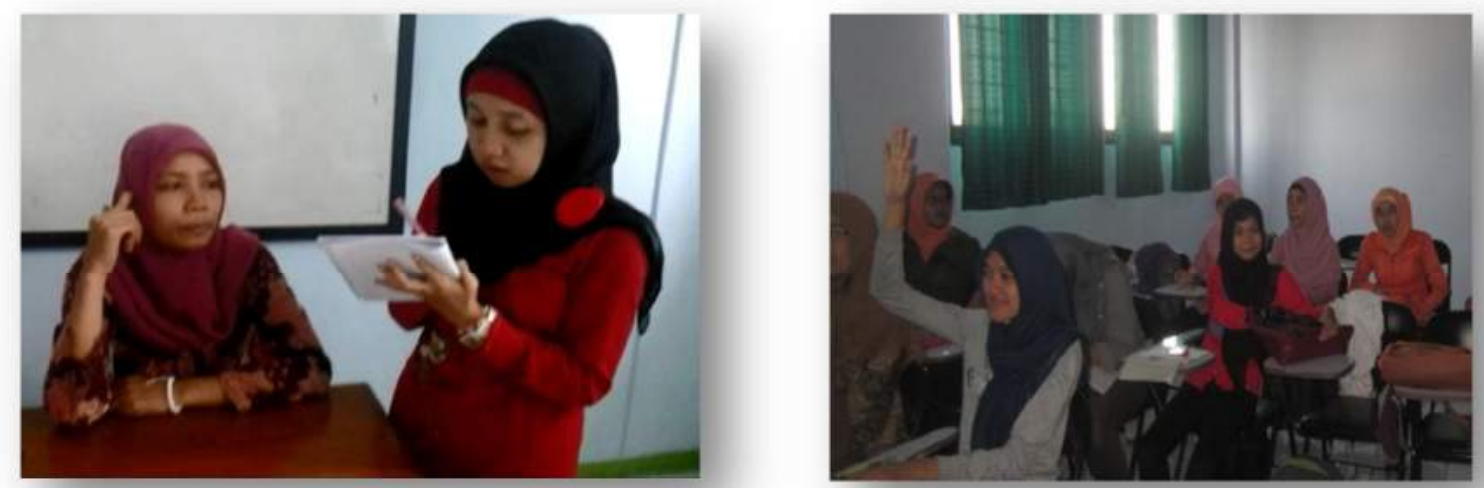

Figure 4. Practicing Scenario

\section{Recording the Teaching Practice into Video}

The video recording of the teaching practice was done by the students. They did it by themselves without lecturer's guidance. The example of students did recording in the classroom is shown in the figure.

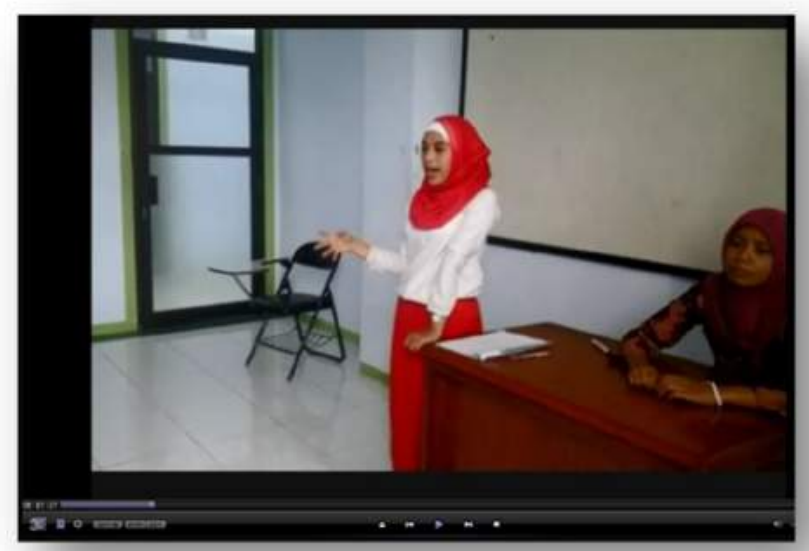

Figure 5. Practicing Scenario

\section{Evaluating the Video Product}

The lecturer asked each group to play video in front of the class. The lecturer together with the students evaluated the video whether the video had reflected the theory of ELT method or not.

Based on the steps in implementing of Project-Based Learning in TEFL class, there are many activities which foster students' critical thinking. The activities are:

\section{Classroom Discussion}

Student discussions can exhibit all phases of inquiry and result in integration and creation of new knowledge, depending on "intensity" of interaction in the integration phase (building on ideas stated by others). It is one of technique to encourage and participation among learners. This activity allows for giving and accepting feedback and for greater reflection. Through classroom discussion, the students must be aware of the significance of their responses and learn to ask good questions of themselves and of others. The questions that focus on the fundamentals of thought and reasoning would form the baseline of critical thinking. Equally important is the role of the lecturer in the classroom discussion. The lecturer must encourage the students to be Reflective, to wait and think, instead of making impulsive judgments, or accepting the first thought that occurs in their mind, or promptly accepting whatever is manifested in the media. The lecturer sometimes formulates questions such as "How do you know"," what are the reasons?" so as to make sure they have underlying reasons for their ideas and to search for rationales for others' views. This will lead to improvement in their critical thinking ability. 
Even though discussion allows for giving and accepting feedback and for greater reflection, it is important for online participants to be aware of the significance of their responses and learn to ask good questions of themselves and of others MacKnight (2000). Questions that focus on the fundamentals of thought and reasoning would form the baseline of critical thinking. Equally important is also the role of the lecturer in the discussion environment to be able to engage in a line of questioning that will continue to drive ideas, and thus help students to develop and apply critical thinking skills (MacKnight, 2000)

\section{Micro Teaching}

Micro teaching is a method of practice teaching in which a videotape of a small segment of a student's classroom teaching is made and participants have an opportunity to analyze the recording of their teaching in structured ways. It functions as a technique that gives student teachers the opportunity to analyze and assimilate different teaching approaches and styles (Hamed, 1979). It also provides immediate feedback that allows discussion and critique of the lessons. Popovich \& Katz (2009) revealed that microteaching is a valuable tool for assisting students in developing communication, critical thinking and problem solving skills. The lecturer can easily control many factors that influence the quality of teaching by means of microteaching.

The Problems Arouse during the Implementation of Project-Based Learning

Some difficulties during the implementation of Project-Based Learning happened are: (1) The lecturer must reformulate the same questions many times in order to make the students get the point of the concept. Some challenging questions such as "Why is it so? What do you think about...? What is your idea about...? etc., can help students think critically. Those questions must be repeated many times to lead the students' understanding. (2) The students feel difficult to translate the concept of ELT Method into teaching scenario. Understanding the concept does not mean constructing the scenario easily. The students need lecturer's guidance in constructing scenario which is matched with the concept. Therefore, the scenario must be revised many times.

\section{The Students' Responses on its Implementation}

Referring to the result of observation and interview to the students, the students showed significantly positive attitude toward the implementation of Project-Based Learning. They were very enthusiastic in doing the project. It can be seen from their participation in discussion time. Most of them tried to give comment dealing with the concept of ELT Method. In addition, they were actively come for face to face consultation to the lecturer in constructing teaching practice scenario.

Even though, this was the first time they experienced Project-based learning. Hence, they had the opportunity to state the possible advantages and challenges of project-based learning. The perceived advantages are: (1) eliminating written examination, (2) learning by doing, and (3) activating participation throughout the course. 


\section{CONCLUSION}

As a final remark, the steps in implementing of Project-Based Learning that fosters students' critical thinking in TEFL 1 class are in the following: (1) Discussing the materials about English language teaching method, (2) working with the group to construct scenario of teaching practice, (3) practicing the scenario, (4) recording the teaching practice into video, and (5) evaluating the

\section{REFERENCES}

Bas, G. (2011). Investigating the Effects of Project-Based Learning on Students' Academic Achievement and Attitudes towards English Lesson. The Online Journal of New Horizons In Education, 1(4).

Beyer, B.K. (1985). Critical thinking: What is it?, Social Education, 49, 270-276.

Bogdan, R.C. \& Biklen, S.K. (1998). Qualitative Research in Education: An Introduction to Theory and Methods. Boston: Allyn and Bacon.

Doppelt, Y. (2003). Implementation and Assessment of Project-Based Learning in a Flexible Environment. International Journal of Technology and Design Education, 13, 255-272.

Fahim, M. \& Sa'eepour, M. (2011). The Impact of Teaching Critical Thinking Skills on Reading Comprehension of Iranian EFL Learners. Journal of Language Teaching and Research, 2(4), 867874.

Fisher, A. (2001). Critical Thinking: An Introduction. Cambridge: Cambridge University Press.

Grant, M. (2006). Getting a Grip on Project-based Learning: Theory, video product. Moreover, the advantages on its implementation are in the form of the abolishing of written examination, the continuation of learning by doing and the active participation.

This research should be repeated with a different course content and target audience. Furthermore, experimental studies may be conducted to reveal the effectiveness of Project-Based Learning.

cases and recommendations. Meridian, 5(1), 1-3 (Online). Retrieved July 12, 2006, from http:/wwww.ncsu.edu/meridian/w in2002/514/3.html.

Halvorsen, A. (2014). Incorporating Critical Thinking Skills Development into ESL/EFL Courses. Internet TESL Journal, 11(3) (Online). Retrieved April 14, 2014

from

http://teslj.org/Techniques/Halvo rsen CriticalThinking.html.

Hamed, C.J.A. (1979). Microteaching Model for Use in Methods Classes. Business Education Forum.

Helm, J.H. \& Katz. L.G. (2001). Young Investigators: The Project Approach in the Early Years. New York: Lecturers College Press.

MacKnight, C. (2000). Teaching critical thinking through online discussions. Educause Quarterly, 4, 38-41(Online). Retrieved July 12, 2006 , from http://net.educause.edu/ir/ibrary/ pdf/EQM0048.pdf

Miles, M.B. \& Huberman, M. (1994). Qualitative Data Analysis: An 
Expanded Sourcebook. Beverly Hills: SAGE Publication Inc.

Perkins, D.N. (2006). What constructivism demands of the learner. Educational Technology, 31, 1823, (Online). Retrieved July 28, 2006 from http://www.ncsu.edu/meridian/w in2002 514 /ndex.html.

Piaget, J. (1969). Science of Education and the Psychology of the Child (Online), Retrieved July 28, 2006 from http:/wwww.ncsu.edu/meridian/w in2002/514/index.html.

Popovich, N.G. \& Katz, N.L. (2009). A microteaching exercise to develop performance based abilities in pharmacy students. American Journal of Pharmaceutical Education, 73(4), 73.
Thomas, J.W. (2014). A Review of Research on Project-Based Learning. (Online) Retrieved on May 18, 2014, from http://www.autodesk.com/founda tion,

Vygotsky, L.S. (1978). Mind in Society: The Development of Higher Psychological Processes. Cambridge, MA: Harvard University.

Westwood, P.S. (2008). What Lecturers Need to Know about Teaching Methods. Victoria: Acer Press. 